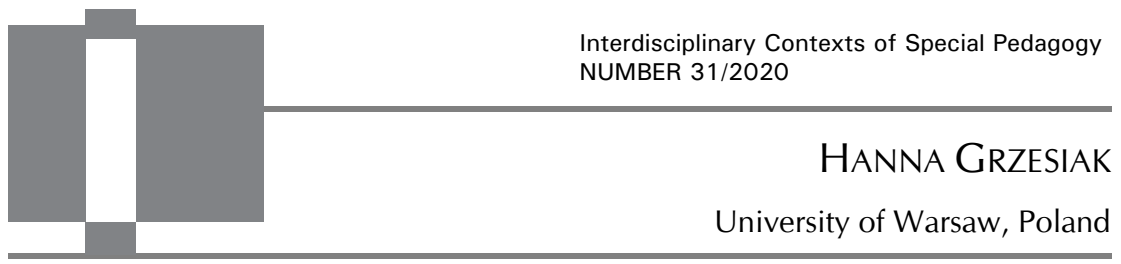

\title{
Dwarfism in ancient times: from worship to rejection
}

\begin{abstract}
Hanna Grzesiak, Dwarfism in ancient times: from worship to rejection. Interdisciplinary Contexts of Special Pedagogy, no. 31, Poznań 2020. Pp. 305-318. Adam Mickiewicz University Press. ISSN 2300-391X. e-ISSN 2658-283X. DOI: https://doi. org/10.14746/ikps.2020.31.14

The objective of this paper is to outline some aspects of dwarfism in the Antiquity. The author focuses in particular on Ancient Egypt where one of the most prominent of gods - Bes - suffered from dwarfism. It was believed that little people were somehow connected to other Egyptians gods, which is why they were treated with respect and dignity. Different attitude towards little people can be seen in Ancient Israel where they were excluded from the society, as disability at the time was considered as a punishment from God. The paper also covers Ancient Greece. Aristotle was the first scholar to describe dwarfism. He noted in particular the intelligence of the little people, which according to him was not developed particularly well, compared to the rest of the society.
\end{abstract}

KEY WORDS: Achondroplasia, disability, Antiquity, culture

Since ancient times, the human kind has been dealing with otherness. That, what is different, alien and unknown has been arousing fear, anxiety, horror, but also fascination. Certainly, people with disabilities constitute one of such groups. These individuals have undoubtedly been, remain and will be an integral and inseparable part of this world. In all cultures, their members make forays into 
trying to explain the essence of disability - they want to know where it comes from, what it is and whether it can be prevented. Answering these questions very often determines how these people are treated by the rest of society, for disability is nothing more than a social and cultural construct. Its origin, causes and patterns of behaviour exhibited towards people with disabilities are understood and perceived differently in different cultures - for example dyslexia, which is considered a disability in many countries, is also underdiagnosed or remains undiagnosed in less developed countries, where access to basic education is very limited. ${ }^{1}$

The presented paper will outline the image of people affected by dwarfism in ancient times. We should start by noting that in spite of the fact that in contemporary times, a little person would certainly be deemed a person with physical disability, they would never be considered to be such in ancient times. The definition of disability, and even more so the classification of disabilities as physical, intellectual, hearing or visual impairment - something, which is a part of our contemporary life - simply did not exist at that time. An individual with any disorder or defect was treated as an "other" or an "alien". According to Zygmunt Bauman, "all societies create their own others, but at the same time, each of them creates the others in their own manner, based on their own image". ${ }^{2}$ However, in order to understand the "other", we also need to understand who is not one, since the "other" does not exist in vacuum or in isolation, hence they should always be viewed in relation to someone else. As Ewa Głażewska points out, the division into categories of "them" and "us" does not necessarily have to be antagonistic in nature, since in many cases, the attitude towards another group can be ambivalent - in this case, in addition to negative features, one also sees the positives. What is more, the relationships between "us" and

${ }^{1}$ Cf. H. Grzesiak, "Kulturowe aspekty niepełnosprawności", [in:] D.M. Piekut Brodzka (ed.), Zrozumieć odmienność, Warszawa, 2011/2012, pp. 34-59.

2 Z. Bauman, "Jak stać się obcym i jak przestać nim być?", [in:] Z. Bauman, Ponowoczesność jako źródto cierpień, Wydawnictwo Sic! s.c., 3nd edition, Warszawa, 2000, p. 35. 
"them" do not have to be based on a binary approach based on a simple opposition - these relations are much more complex, opaque, ever-changing and multi-faceted, leading to situation where one of "us" can also be the "other", the "other" can be one of "us", there are enemies among "us" and friends among "them". ${ }^{3}$

\section{Causes of growth deficiency}

The definition of growth deficiency is purely conventional in nature and based on statistical data. Standards in medicine are usually defined as a value within \pm 2 standard deviations from the average for a given characteristic, hence growth deficiency is usually defined as a height of less than two standard deviations from the average for a given age and gender. 4

One of the most common forms of dwarfism is achondroplasia this disease is a genetic skeletal development disorder, which results in impairment of intra-articular ossification. Achondroplasia results in the shortening of limbs, enlarged foramen magnum, narrow intervertebral foramen, and underdeveloped base of skull. The most characteristic symptom of this disease are shortened limbs, in particular their proximal parts. Women with achondroplasia, assuming the correct development of the torso, can have a height of 123 centimetres, while men can get taller and reach 132 centimetres. The prevalence of the disease is equal for both sexes.

It is estimated, depending on various statistics, that one in every 15,000 to 30,000 children is born with this developmental disorder. The disease stems from a mutation of a gene encoding the fibroblast growth factor receptor 3 (FGFR - 3), which is located on the short arm of chromosome 4. Achondroplasia is a familial disorder; how-

${ }^{3}$ E. Głażewska, “Inny/obcy jako uosobienie diabła”, Kultura i historia, 32/2017, p. 132.

4 U. Oczkowska, “Definicja i przyczyny niskorosłości oraz kryteria diagnostyczne niedoboru hormonu wzrostu", Endokrynol. Ped., vol. 9/2009, appendix 1, p. 6. 
ever, it is usually caused by fresh mutations, and their likelihood increases with the father's age. ${ }^{5}$

Pathological causes of growth deficiency also include nutritional deficiencies - in particular microelements, such as zinc and iron, as well as chronic malnutrition. Other factors include hormonal disorders such as hypothyroidism and hypopituitarism. Another category includes chromosomal aberrations, comprising Turner syndrome, Down syndrome, Prader-Willi syndrome. These days, many of these diseases can be treated with growth hormone. ${ }^{6}$ Achondroplasia is an exception to that rule. The only clinical intervention available for people with achondroplasia is surgical bone lengthening, which sparks many controversies. ${ }^{7}$ In ancient times, however, these treatments did not exist at all. ${ }^{8}$

\section{Dwarfism in Ancient Egypt}

Ancient Egypt offers us a trove of knowledge about dwarfism. We have the data concerning little people thanks to well-preserved biological remains such as bones or entire skeletons. The list of source material also includes numerous works of art which have survived to the present day, showing people with deformations. However, there is no written testimony or medical papyrus that

${ }^{5}$ Cf. M. de Mezer, "Historia badań nad genezą oraz rozwojem terapii achondroplazji", Nowiny Lekarskie, 2009, 78, pp. 5-6, pp. 368-370, B.M. Adelson, Dwarfism. Medical and Psychosocial Aspects of profund short stature. Baltimore, London: The Johns Hopkins University Press, 2005, pp. 17-21.

${ }^{6}$ Cf. U. Oczkowska, “Definicja i przyczyny niskorosłości oraz kryteria diagnostyczne niedoboru hormonu wzrostu", Endokrynol. Ped., vol. 9/2009, appendix 1, pp. 6-7.

7 S. Chilbule, V. Dutt, V. Madhuri, "Limb lengthening in achondroplasia", Indian Journal of Orthopaedics, 50(4), 2016, pp. 397-405.

8 J.E. Molto, C.L. Kirkpatric, "How Short Is Short, and Why? A Probable Case of Proportionate Dwarfism From Egypt's Third Intermediate Period in the Dakhleh Oasis, Egypt", International Journal of Osteoarchaeology Int. J. Osteoarchaeol, 28(2018), p. 3. 
would present and describe a person affected by achondroplasia. ${ }^{9}$ Véronique Dasen points out that dwarfism was probably the most common form of physical deformity in ancient times ${ }^{10}$ and the first biological source - an almost-intact skeleton, which confirms the existence of dwarfism, dates back to the Predynastic Period, around 4500 BC. 11

The literal translation of the term $n m w$ in ancient Egypt was "dwarf". It was accompanied by a pictogram depicting a little man with short limbs and slightly extended buttocks, suggesting that the depicted person suffered from lordosis, a spinal disease. ${ }^{12}$

It was believed that little people were somehow connected to other Egyptians gods, which is why they were treated with respect and dignity. One of the most interesting facts is that the pantheon of Egyptian gods included Bes - the Little God, who, despite not being commonly known at the beginning, became one of the most important among Egyptian deities over time.13

The etymology of his name remains unknown. He was depicted as a strange bearded dwarf with lion or cat ears, a tail, a large head with protruding eyes, a long tongue stretching out to his chin and enormous genitals. In many cases, his phallus was split or depicted as erect, which undoubtedly symbolised the powerful and lifegiving power of nature. His head was often crowned with a crown of ostrich feathers, and he was wearing lion, leopard or panther skin. He was said to be responsible for the proper course of all life processes, he chased away evil forces and protected the sleeping people from nightmares. Another interesting aspect is the fact that

${ }_{9}$ Ch. Kozma, "Dwarfs in Ancient Egypt", American Journal of Medical Genetics, 2006, pp. 303-304.

${ }^{10} \mathrm{~V}$. Dasen, "Dwarfism in Egypt and classical antiquity: Iconography and medical history", Medical History, 32(1988), p. 254.

${ }^{11}$ Ch. Kozma, Historical Review, American Journal of Medical Genetics, 140A (2006), p. 303.

12 V. Dasen, "Dwarfism in Egypt and classical antiquity: Iconography and medical history", Medical History, 32(1988), p. 258.

${ }^{13}$ A. Niwiński, "Bóstwa, kulty i rytuały starożytnego Egiptu", Pro-Egipt, Warszawa, 1993, p. 328. 
in some works of ancient Egyptian literature Bes is presented as a giant dwarf that stands tall from the underground world to the sky. He was also a patron of games and music. ${ }^{14}$ He also protected new-born children and their mothers. ${ }^{15}$

Ancient Egyptians also followed Beset, Bes' female counterpart, who was responsible for the same areas, and she was also depicted as a dwarf - just like Bes. For this reason they were sometimes said to be twins, twins and children of Shu and Tefnut. Shu represented the dry air and the foundations of the world, while Tefnut represented water - the key to existence. ${ }^{16}$

Although this deity had no temple in Egypt, there was a famous oracle in Abydos, who was tasked with explaining dreams for people from all over Egypt and other neighbouring countries. ${ }^{17}$

Certainly the image of Bes was born as a result of the ancient Egyptians' encounters with disability. According to Ewa J. Zgolinska: "The depictions of Bes, his history, his transformations and at the same time the permanence of his cult over so many centuries allow us to suppose that this god not only familiarised people with the phenomenon of disability, but above all allowed them to understand it, while bringing the worlds of gods and people closer together". ${ }^{18}$ We should note that Bes was also a guardian god, safeguarding homes and families, not a god who brought people misery or disease. This leads us to a conclusion that disability was not sup-

${ }_{14}$ W. Bator, Religia starożytnego Egiptu, Wydawnictwo WAM, Kraków, 2004, p. 167; G. Pinch, Handbook of Egyptian Mythology, ABC-CLIO, Santa Barbara, Denver, 2002, pp. 118-119.

15 K. Nitka, "Przedstawienia Besa w zbiorach Muzeum Narodowego", Rocznik Muzeum Narodowego w Warszawie, vol. XIV, 1970, p. 22.

16 G. Pinch, Handbook of Egyptian Mythology, ABC-CLIO, Santa Barbara, Denver, 2002, p. 118; W. Bator, Religia starożytnego Egiptu, Wydawnictwo WAM, Kraków, 2004, p. 205.

17 W. Bator, Religia starożytnego Egiptu, Wydawnictwo WAM, Kraków, 2004, p. 168.

18 E.J. Zgolińska, “Między groteską a metaforą - czyli starożytnych Egipcjan pojmowanie niepełnosprawności, [in:] J. Baran, S. Olszewski (eds.), Świat pełen znaczeń - kultura i niepetnosprawność, Impuls, Kraków, 2006, pp. 533-534. 
posed to be seen as something evil or negative - instead, the goal was to integrate healthy individuals with persons with disabilities, just like Bes was bringing the family together.

Another noteworthy thing is that Bes was not the only deity with disabilities - this list also included Ptah (although not all preserved figures depict him as a little person), who - according to ancient Egyptian beliefs - made man out of clay and breathed life into him. His name means "to open" and he was revered as the creator of the universe and the god of regeneration. However, unlike Bes, who had many animal features, he was presented as a naked man with features of a little person. ${ }^{19}$

People of low stature were often depicted on amulets, which were supposed to protect against evil forces and bring luck. Some women also tattooed their bodies with the image of Bes, which symbolised fertility and served as a sexual symbol as well. ${ }^{20} \mathrm{Nu}-$ merous papyruses, in particular those from the New Kingdom of Egypt, contain invocations to dwarves, who were entrusted with the lives of the living, and who were supposed to protect them from evil powers or animals - in particular from snakes, of which there were many in Egypt. On one of the papyruses, we find the following invocation: "Oh, heavenly dwarf, oh, heavenly dwarf. Oh, you dwarf with a beautiful face, large back and short limbs. Oh, you wonderful pillar stretching from the sky to the underground world. Lord of the great body that rests in Heliopolis. Oh, great lord" ${ }^{21}$

Pregnant women also called upon dwarves, pleading for a quick and safe birth. As we read on one papyrus from Leiden, women uttered the following prayer: "Oh, good dwarf, come, on behalf of the one who sent you, may the placenta lower, may the placenta lower". This prayer was uttered four times over a clay statue of

${ }^{19}$ Ch. Kozma, "Dwarfs in Ancient Egypt", American Journal of Medical Genetics, 2006, p. 308.

${ }^{20}$ G. Pinch, Handbook of Egyptian Mythology, ABC-CLIO, Santa Barbara, Denver, 2002, p. 118.

${ }^{21}$ Leitz, after: Ch. Kozma, "Dwarfs in Ancient Egypt", American Journal of Medical Genetics, 2006, p. 310. 
a dwarf, which was then placed on top of the head of the woman giving birth. ${ }^{22}$

Dwarves were also painted in tombs during the Old Kingdom Period. Most of their images were found in Giza and Saqqara. The paintings show that these people were mostly making jewellery, selling animals, fishing or providing entertainment by dancing. ${ }^{23}$

It is therefore clear that people of short stature had a privileged position in society. What is more, it is worth mentioning at this point that unlike other ancient cultures, ancient Egypt is one of the few ancient civilizations where individuals with disabilities were treated with respect and cared for. In the Antique period, disability was treated as a punishment for sins, and people affected by it were ostracised and in many cases also deprived of their rights. Moreover, in Ancient Greece or Rome, people with disabilities were most often killed or left alone without any care. Even if they survived the first days of their lives, they died later, because there were no people willing to take care of a disabled child and make them a part of their family. ${ }^{24}$

\section{Dwarfism in Ancient Israel}

In Ancient Israel, there were no medical texts that would confirm the existence of dwarfism, which does not mean that it did not exist. In the Hebrew Bible, in the Book of Leviticus, we read the following passage:

"No man who has any defect may come near: no man who is blind or lame, disfigured or deformed; no man with a crippled foot or hand, or who

22 J.F. Borghouts, The magical tests of papyrus Leiden. Leiden, Brill Publishing Company, 1971, p. 29.

${ }^{23}$ Ch. Kozma, "Dwarfs in Ancient Egypt", American Journal of Medical Genetics, 2006, p. 309.

${ }^{24}$ Cf. A. Pankalla, Psychologia mitu. Kultury tradycyjne a współczesność, Eneteia, Warszawa, 2000, p. 110; R. Garland, The Eye of the Beholder: Deformity and Disability in the Greco-Roman World, Cornell University Press, New York 1995. 
is a hunchback or a dwarf, or who has any eye defect, or who has festering or running sores or damaged testicles. No descendant of Aaron the priest who has any defect is to come near to present the food offerings to the LORD". 25

Reading, at first glance, one can notice that the above fragment has no passage that would concern little people, but in reality, it does. The above translation, taken from the Millennium Bible, translates the Hebrew word ד (dak) as impaired. The reader immediately imagines intellectual disabilities or mental disorders, which are very often associated with this term, Thus, this term stigmatises individuals affected by these mental states. Meanwhile, this term, translated from Hebrew, means "thin" or "fine". In other words, it refers to a person whose body and not mind is impaired. It is therefore clear that this passage may concern people afflicted by achondroplasia.

The above passage concerned priests who made sacrifices in the days of ancient Israel when the Temple of Jerusalem still existed; and as such, they had the most important function in society. They were intermediaries between the entire Israeli society and Yahweh himself. Because Yahweh was a perfect god, the people who offered him sacrifices had to be clean, perfect and devoid of the slightest flaw. Achondroplasia therefore undermined and removed the afflicted person from the consideration.

In Talmud, which - in addition to the Torah - constitutes the foundation of Judaism, we read that a man of a short stature should not marry a woman of similar height. There was a fear that the offspring to be born from this relationship would also be short. ${ }^{26}$

In one of the Talmudic treaties we read Rabbi Yehoshua Ben Levi saying: One who saw a person with unusually black skin, a person with unusually red skin, a person with unusually white skin [lavkan], an unusually tall and thin person, a dwarf, or one with warts [darnikos] recites: Blessed... Who makes creatures dif-

${ }^{25}$ Leviticus, 21, pp. 18-21.

26 Berakhot $45 \mathrm{~b}$. 
ferent. However, one who sees an amputee, a blind person, a flatheaded person, a lame person, one afflicted with boils, or spotted people recites: Blessed... the true Judge, not: Who makes creatures different! 27 It seems to me that the above passage from Talmud does not imply the acceptance of people who were different. In ancient Israel, disability was treated as a punishment for sins. ${ }^{28}$ People widely recognised disability as a consequence of failure to live by the commandments given by Yahweh. Those afflicted by disability were often stigmatised and chased away from the society, and what is more, they had no way to participate in the religious life of the community, which was undoubtedly the greatest punishment for every pious Jew. Thus, the author believes that the above passage was only meant to highlight that every being, both physically and mentally perfect and imperfect with clear body deformities, comes from Yahweh himself. Thus the words spoken in front of these people were to signify both the power of God - the Creator - and to instil fear of him. It was probably also meant to be a signal to every Jew that opposition or skirting the divine commandments could result in a visible impairment of their bodies, and as such, disability was meant to be treated as a warning to others.

\section{Dwarfism in Ancient Greece}

Ancient Greeks also knew dwarfism. However, in comparison with ancient Egypt, where the desert climate contributed to the good preservation of the remains, Greek fossil record is scarce, mainly due to the fact that cremation remained a popular form of burial. ${ }^{29}$

Aristotle was the first scholar to describe little people. He pointed out that people affected by dwarfism have a disproportionately

\section{Berakhot $58 b$.}

${ }^{28}$ Cf. H. Grzesiak, “Osoby głuche w świetle judaizmu”, Niepetnosprawność i Rehabilitacja, 4 (2010), pp. 132-144.

${ }^{29}$ Cf. J. Musgrave, “Dust and Damn'd Oblivion: A study of cremation in Ancient Greece", The Annual of the British School at Athens, Vol. 85(1990), pp. 271-299. 
large upper body part compared to the very small lower part. He also noted that - like mules - their genitals were much larger than average. The scholar also claimed that their large torso contributes to numerous metabolic disorders of the body, while suggesting that dwarves, like children, sleep longer than other people. This is due to the fact that the heat that is supplied by eating food is cooled down due to the large size of their torso. Then the cold moves down the body and thus paralyses the whole system, so that a person needs more sleep, compared to a healthy person. Aristotle pointed out that these people have enlarged genitals. He also thought that their intelligence is less developed, because the weight of the upper body impairs the functioning of memory. 30 These days, we know he was wrong because the intelligence of the little people is comparable to the average level of intelligence in society. ${ }^{31}$

Hippocrates also tried to explain the causes of dwarfism. In one of the treatises he describes how a child is born leptos (small) asthenes (weak) or anaperos (with disability). These disorders, according to him, were connected with foetal development. This is due to a too narrow or not very well closed uterus and a lack of appropriate nutrients during the foetal growth period. This process is compared to the growth of a cucumber in a vessel - the plant takes its shape and size from the vessel in which it is placed. ${ }^{32}$

Dasen points out the fact that apart from Aristotle and Hippocrates there were no further medical information on dwarfism. This may mean that these people were born relatively rarely and died quickly, or that dwarfism was not treated as an illness and did not require medical attention nor care..$^{33}$

30 After Aristotle: V. Dasen, “Dwarfism in Egypt and classical antiquity: Iconography and medical history", Medical History, 32(1988), p. 268.

31 Cf. B.M. Adelson, Dwarfism. Medical and Psychosocial Aspects of profund short stature. Baltimore, London: The Johns Hopkins University Press, 2005, pp. 118-125.

32 After Hippocrates: V. Dasen, "Infirmitas or not? Short - statured persons in Ancient Greece", [in:] Krotzl C., Mustakallio K., Kuuliala J., Infirmity in Antiquity and the Middle Ages. Social and Cultural Approaches to Health, Weakness and Care. London, New York: Routledge, 2016, p. 33.

33 V. Dasen, "Infirmitas or not? Short - statured persons in Ancient Greece", [in:] Krotzl C., Mustakallio K., Kuuliala J. Infirmity in Antiquity and the Middle Ages. 
In ancient Greece, the cult of beauty was particularly prominent, as human beings were supposed to be as beautiful and perfect as the gods who - as they believed - resided on Mount Olympus. For this reason, people with deformed bodies were not represented in $\operatorname{art}^{34}$, as they aroused disgust and fear in the viewers. In many cases, such people were avoided, as it was believed that disability is a punishment for offences and can be contagious. Thus, when a child with a visible defect was born, it was often killed.

It is therefore surprising that people with achondroplasia were often depicted on ceramic products or on walls of houses, mostly dancing - individually or in pairs. Based on all the preserved materials, the depictions presented mostly men. The image of a little woman appeared only once. The author believes that it is very likely that due to their appearance, these people were supposed to be an attraction and entertainment for the society, because in many cases they were depicted as dancing and making other people smile. Their body was not deformed in any way - they were not missing any limbs or twisted, which could arouse fear and terror amongst others. Due to their short stature, they may have been perceived as agile, energetic and funny children, who are not to be feared, because they would not do any harm.

Unfortunately, apart from artworks and fragments of medical descriptions, mostly written by Aristotle, we do not have any information about the place of these people in social life and their functions.

\section{Conclusions}

The above historic-cultural outline shows that the attitude towards little people was ambivalent - from the marginalisation and

Social and Cultural Approaches to Health, Weakness and Care. London, New York: Routledge, 2016, p. 33

${ }^{34}$ Cf. V. Dasen, "Dwarfism in Egypt and classical antiquity: Iconography and medical history", Medical History, 32(1988), p. 254. 
rejection encountered in the religion of ancient Israel, to worshipping seen in ancient Egypt.

These days, it may seem that the vast majority of society treats people with achondroplasia as equals, there are still individuals, for whom short stature is a reason for jokes or insults. Therefore, we should keep in mind that every person is a unique, and the way we interact with others shows what kind of people we are.

\section{References}

Adelson B.M., Dwarfism. Medical and Psychosocial Aspects of profund short stature. Baltimore, London: The Johns Hopkins University Press, 2005.

Ashkenazi M., Handbook of Japanese Mythology, Santa Barbara, Denver, Oxford ABC-CLIO, 2003.

Bator W., Religia starożytnego Egiptu, Wydawnictwo WAM, Krakow, 2004.

Borghouts J.F., The magical tests of papyrus Leiden. Leiden, Brill Publishing Company, 1971.

Dasen V., "Dwarfism in Egypt and classical antiquity: Iconography and medical history", Medical History, 32 (1988).

Dasen V., "Infirmitas or not? Short - statured persons in Ancient Greece", [in:] Krotzl C., Mustakallio K., Kuuliala J. Infirmity in Antiquity and the Middle Ages. Social and Cultural Approaches to Health, Weakness and Care. London, New York: Routledge, 2016.

Flower L., The elements of world religions, Shafetsbury, Element, 1997.

Garland R., The Eye of the Beholder: Deformity and Disability in the Greco-Roman World, Cornell University Press, New York, 1995.

Głażewska E., "Inny/obcy jako uosobienie diabła” Kultura i historia, 32 (2017).

Grzesiak H., “Osoby głuche w świetle judaizmu”, Niepetnosprawność i Rehabilitacja 4 (2010).

Grzesiak H., "Kulturowe aspekty niepełnosprawności", [in:] D.M. Piekut-Brodzka (ed.), Zrozumieć odmienność, Warszawa, 2011/2012, pp. 34-59.

Kozma C., Dwarfs in Ancient Egypt, American Journal of Medical Genetics, 2006.

de Mezer M., "Historia badań nad genezą oraz rozwojem terapii achondroplazji", Nowiny Lekarskie, 2009, 78, pp. 5-6.

Musgrave J., "Dust and Damn'd Oblivion: A study of cremation in Ancient Greece", The Annual of the British School at Athens, Vol. 85(1990), pp. 271-299.

Nitka K., "Przedstawienia Besa w zbiorach Muzeum Narodowego", ,Rocznik Muzeum Narodowego w Warszawie, vol. XIV, 1970. 
Niwiński A., "Bóstwa, kulty i rytuały starożytnego Egiptu”, Pro-Egipt, Warsaw, 1993.

Oczkowska U., “Definicja i przyczyny niskorosłości oraz kryteria diagnostyczne niedoboru hormonu wzrostu", Endokrynol. Ped., vol. 9/2009, appendix 1, pp. 6-2.

Pankalla A., Psychologia mitu. Kultury tradycyjne a wspótczesność, Eneteia, Warszawa, 2000.

Pinch G., Handbook of Egyptian Mythology. ABC-CLIO, Santa Barbara, Denver, 2002

Strutynski U., "History and Structure in Germanic Mythology: Some Thoughts on Einar Haugen's Critique of Dumezil”, [in:] G.J. Larson, C.S. Littleton, J. Puhvel (eds.), Myth in the Indo- European Antiquity, University of California Press, London, 1974.

Waldenfels K., Leksykon religii. Zjawiska - dzieje-idee. VERBINUM, Warszawa, 1997.

Zgolińska E.J., "Między groteską a metaforą - czyli starożytnych Egipcjan pojmowanie niepełnosprawności", [in:] J. Baran, S. Olszewski (eds.) Świat pełen znaczeń - kultura i niepetnosprawność, Impuls, Kraków, 2006. 